\title{
POLD3 Gene
}

National Cancer Institute

\section{Source}

National Cancer Institute. POLD3 Gene. NCI Thesaurus. Code C106227.

This gene plays a role in the optimization of DNA replication. 